\title{
3 Research Square

\section{Extracting and physicochemical properties of carotenoprotein from shrimp processing waste by proteases-mediated hydrolysis}

Parastoo Pourashouri ( $\sim$ pourashouri.p@gmail.com )

Gorgan University of Agricultural Sciences and Natural Resources https://orcid.org/0000-0002-13667598

\section{Hojat Mirsadeghi}

Gorgan University of Agricultural Sciences and Natural Resources

\section{Aynaz Khodanazary}

Khorramshar Marine Science and Technology University: Khorramshahr Marine Science and Technology University

\section{Research Article}

Keywords: Carotenoprotein, enzymatic hydrolysis, Shrimp waste, mineral content

Posted Date: February 25th, 2021

DOI: https://doi.org/10.21203/rs.3.rs-234608/v1

License: (c) (i) This work is licensed under a Creative Commons Attribution 4.0 International License. Read Full License

Version of Record: A version of this preprint was published at Waste and Biomass Valorization on September 3rd, 2021. See the published version at https://doi.org/10.1007/s12649-021-01561-4. 


\section{Abstract}

In this study, carotenoprotein from Pacific white shrimp (Litopenaeus vannamei) processing waste was extracted with the aid of alcalase (CP-A) and pepsin (CP-P) at various levels (0-4 units $/ 100 \mathrm{~g}$ waste) for different times (0-240 min). Recovery of carotenoids and protein increased with increasing enzymes levels ( 3 unit/g) and hydrolysis times until $180 \mathrm{~min}(\mathrm{p}<0.05)$. The extracted carotenoprotein by pepsin and alcalase consisted of $72.11-75.32 \%$ protein contents and carotenoids were in the range of 330-530 $\mu \mathrm{g} / \mathrm{g}$ samples. The phenylalanine, lysine, methionine and valine as essential amino acids were high at CP-A and CP-P. The dominant non-essential amino acids in carotenoproteins were aspartic acid, glutamic acid, glycine and alanine. It was rich in mono and polyunsaturated fatty acids. The CP-A showed higher DHA and EPA (8.52 and 6.49\%) than CP-P (5.55 and 5.49\%). The saturated fatty acids were reduced after enzymatic hydrolysis and contents were higher in carotenoproteins. The extracted samples showed a significant amount of mineral contents. Sodium, phosphorus, magnesium and potassium contents were found to be higher in CP-A. The lead and copper reduced as a result of hydrolysis. Therefore, carotenoprotein from processing residue of pacific white shrimp could be used as the value-added nutritious enriching food or feed powder.

\section{Statement Of Novelty}

Extraction of carotenoprotein could be valorize shrimp waste and reduce environmental problems. These residues are one of the problems of shrimp processors in developing countries. Lots of researchers evaluated the extraction of carotenoprotein under various conditions in their work. In the present work, carotenoproteins were prepared by two types of common enzymes.

The obtained data can be useful in the option of the find a suitable method to producing carotenoprotein for animal feed or food. It suggests that other ways is better to investigate and a comparison could be helpful.

\section{Introduction}

Annually, a substantial content of residues, by-products, and wastes produces by fish and crustacean processing industry. This discards, burden severe environmental and ecological influences, also have considerable effects on the economic viability of the fisheries sectors [1, 2]. In recent years, growing considerations have been given to the waste of shrimp processing [3, 4]. The shrimp processing generates considerable quantities of waste in the form of heads, tails, and cephalothorax; which these large amounts of discards cause some problems [5, 6]. Approximately 50-70\% of the whole weight of the raw material estimates as the wastes of shrimp processing. These residues have been explored as a potential and rich source of chitin, protein, carotenoid, shrimp hydrolysate, shrimp flavorant, nutritive components, PUFA and enzymes [5, 7, 8]. In Iran, a small quantity of the waste is being used as manure and animal feed mix. Thus, the large quantity of this organic waste is a problem for processors while can be a potential source of bioactive products. 
Today, many researchers no longer bring up shrimp by-products as waste and instead it is known as a raw material which is prepared to usage in other processes [9]. Carotenoid and carotenoproteins have been known as bioactive compounds that have potential to use as natural colorant, antioxidant, antimicrobial agents in different industries such as food, pharmacology, textiles, chemical and feed [5, 8, $10,11]$. Carotenoproteins is a protein-pigment complexes are stable products which carotenoids by binding to the protein (hydrophobic sites) will be more stable [12]. Therefore, using such discards is of economic value and has drawn more attention in recent years $[3,10]$. Investigates have been carried out on isolation of carotenoproteins from shrimp and crab processing discards by using different methods such as autolytic hydrolysis [5], enzymatic hydrolysis [2, 13], and fermentation [14]. Shrimp waste hydrolysate can be as a biological source of active peptides with considerable potential in pharmacology, anti-cancer activity and/or as growth-stimulating agents in animal feeds $[15,16]$. Work on the application of extracted alkaline proteinases from fish viscera can be found for extraction of carotenoproteins $[8,17]$ and this compound was studied as an antioxidant agent in system models [18].

According to previous studies, enzymatic hydrolysis seems one of the suitable methods to increase the efficiency extraction of caroteneproteins [8]. The hydrolysis condition is effective on yield and characteristics of carotenoprotein from shrimp processing waste. Therefore, the present study investigates the impact of hydrolysis using Alcalase and pepsin on the extraction of carotenoproteins from Pacific white shrimp waste processing. Furthermore, this study aimed to describe some biochemical characteristics, mineral content and nutritional characteristics such as amino and fatty acids contents of extracted carotenoproteins.

\section{Material And Methods}

\subsection{Chemicals}

Alcalase (Bacillus licheniformis, 2.4 AU-A/g) was obtained from Novozymes (Bagsvaerd, Denmark) and pepsin (porcine gastric mucosa), bovine serum albumin (BSA), Boron trifluoride (BF3), fatty acid standards, were obtained from Sigma-Aldrich (St Louis, Mo, USA). All other chemicals used were of analytical grade and supplied by AppliChem (GmbH, Darmstadt, Germany) and Merck (KGaA, Darmstadt, Germany).

\subsection{Preparation of raw material}

Shrimp processing waste (a mixture of cephalothorax, shell, and tail) were obtained Litopenaeus vannamei (Shilabzi shrimp processing Co., Golestan, Iran). The waste was transported to the laboratory within 30 min; upon arrival, the raw waste was grounded by food processor (Panasonic, Malaysia Sdn Bhd.), was packed and stored in polyethylene bags at $-20^{\circ} \mathrm{C}$ until the experiment.

\subsection{Extraction of carotenoprotein using proteases}


Carotenoproteins (CP-A and CP-P) extraction from shrimp waste was performed according to Chakrabarti (2002) and Sila, Nasri, and Bougatef (2012). At the first, the optimal concentration of enzymes (pepsin and alcalase) and time of hydrolysis were determined. $25 \mathrm{~g}$ of homogenized wastes were mixed with EDTA buffer solution $(0.5 \mathrm{M})$ in a ratio of $1: 2.5$ and the $\mathrm{pH}$ of the mixture was adjusted (pepsin, 2 \& alcalase, 8). Enzymes were added ( 0 to $4 \mathrm{U} / \mathrm{g}$ ) and the mixture incubated for $0,60,120,180$ and $240 \mathrm{~min}$ (rpm 200) (IKA-Werke GmbH \& Co. KG, Staufen Germany). At the end, the mixture was filtered via a multilayer cleaning cloth; the $\mathrm{pH}$ was adjusted to $4.5(\mathrm{HCl} 2 \mathrm{M})$ and was centrifuged at $5000 \mathrm{rpm}\left(4^{\circ} \mathrm{C}, 20\right.$ $\mathrm{min}$ ), then it was dissolved in $20 \mathrm{ml}$ of $5 \mathrm{mmol}$ sodium phosphate buffer $(\mathrm{pH}=7)$ and lyophilized (Christ, ALPHA 2-4 LSC, Gmb, Germany). The dried CPs was stored in tightly closed plastic containers. The optimal condition of hydrolysis was determined based on the recovery protein and carotenoid contents.

\subsection{Total carotenoid}

Total carotenoid in the waste and CPs was measured (Simpson and Haard, 1985). $1 \mathrm{~g}$ of the sample was mixed with acetone $(25 \mathrm{ml})$ and homogenized $(2 \mathrm{~min}, 16000 \mathrm{rpm})$; then filtered (Whatman paper filter, No.1) and was drained in a separating funnel and was subdivided with an equal volume of petroleum ether. The separatory funnel was shaken and stands for $30 \mathrm{~min}\left(24^{\circ} \mathrm{C}\right)$. The top layer was washed twice with an equal volume of water. The petroleum ether layer obtained was passed and dehydrated by anhydrous $\mathrm{Na} 2 \mathrm{SO} 4$. All petroleum ether was evaporated by rotary at vacuum condition. The residue was appropriately diluted in petroleum ether $(10 \mathrm{ml})$ and the absorbance was read at $468 \mathrm{~nm}$. The carotenoid content $(\mu \mathrm{g} / \mathrm{g})$ in shrimp waste and prepared sample was calculated by the equation (1); which 0.2 is the absorbance of standard astaxanthin $(1 \mathrm{mg} / \mathrm{ml})$.

Carotenoid content $=\frac{\text { absrbance }(\text { A468 }) \times \text { volume } \times \text { dilutin factor }}{0.2 \times \text { sample weight }}$

\subsection{Protein Recovery of hydrolyzed shrimp waste}

Protein solubility was measured at the different time according to the biuret method [19]. $100 \mathrm{mg}$ of the sample was mixed by $0.5 \mathrm{M} \mathrm{NaOH}(10 \mathrm{ml})$ at $85^{\circ} \mathrm{C}$. After $1 \mathrm{~h}$ incubation, the samples were centrifuged (5000 rpm, $20 \mathrm{~min}$ ); the supernatant was tested for protein content. The bovine serum albumin (BSA) was applied as the standard and the results were reported in $\mathrm{mg} / \mathrm{mL}$ by BSA standard curve [11].

\subsection{Proximate Analysis and Chitin content}

The moisture, protein, fat, and ash contents of the uniformly grounded waste and CPs were estimated by standard methods [20]. To determine of chitin content, $2 \mathrm{~g}$ of sample was mixed by $30 \mathrm{ml}$ of $\mathrm{NaOH}(2 \%$, $\mathrm{w} / \mathrm{v}$ ) for $6 \mathrm{~h}$ at $25 \mathrm{C}$. After incubation ( $6 \mathrm{~h}$ ), the mixture was filtered (Whatman paper filter, No.1) and was incubated with $\mathrm{HCl}(1 \mathrm{mM})$ for $30 \mathrm{~min}\left(25^{\circ} \mathrm{C}\right)$. After the filtration, samples washed and the pigment removed by vigorously homogenized (Ultraturax, IKA-Werke GmbH \& Co. KG, Staufen Germany) with cold acetone (14000 rpm, $5 \mathrm{~min}$ ). Then, it was washed by the water and mixed with $\mathrm{NaOCl}(0.3 \%)$. After 
incubation for $6 \mathrm{~h}$ at $25^{\circ} \mathrm{C}$, the sample was filtered and washes with distilled water and was dried (24h, $\left.60^{\circ} \mathrm{C}\right)$. The chitin content was expressed as a percentage.

\subsection{Determination of color}

Color was measured using a Lovibond CAM-System 500, Colorimeter Imaging (Tintometer Ltd., Amesbury, UK). The color ( $L^{*}$, lightness; $a^{*}$, redness/greenness; and $b^{*}$, yellowness/blueness) indexes were reported in the CIE system.

\subsection{Determination of amino acid}

The amino acids composition of SW and CPs was analyzed by following the method of Matloubi et al. (2004). The sample was analyzed through hydrolysis of samples using $6 \mathrm{M} \mathrm{HCl}\left(1 \mathrm{~h}, 110{ }^{\circ} \mathrm{C}\right)$. After cooling, an aliquot of the sample was subjected to neutralization $(\mathrm{pH} 1.5-5)$. Derivatization of amino acids was done by phenyl isothiocyanate. The amino acid standard and hydrolysates were dissolved in $100 \mathrm{~mL}$ buffer; $1-10 \mathrm{~mL}$ of the solutions was analyzed by reverse-phase HPLC (PerkinElmer, Shelton, CT, USA). Tryptophan was measured, separately.

\subsection{Determination of fatty acid composition}

Fatty acid compositions of SW and CPs were defined as fatty acid methyl esters (FAMEs) according to Metcalfe and Schmitz [21] using a gas chromatograph (GC Hewlett Packard 5890 series, Avondale, PA., USA); which provided with flame ionization detector. MEs were acquired from fatty acids in the lipid extract of samples through Boron trifluoride esterification. The MEs were afterwards dissolved in nheptane and were injected into the GC and breakdown was carried out on a fused silica capillary column ( $30 \mathrm{~m} \times 0.32 \mathrm{~mm}, 0.25 \mu \mathrm{m}$; Supelco, Bellefonte, PA, USA). The Helium was used as a carrier gas. The initial temperature of the oven was introduced at $160^{\circ} \mathrm{C}$ and went up to $200^{\circ} \mathrm{C}\left(3^{\circ} \mathrm{C} / \mathrm{min}\right)$ and continued for $1 \mathrm{~min}$. It was more increased to $220^{\circ} \mathrm{C}$ at $3^{\circ} \mathrm{C} / \mathrm{min}$ and the temperature was kept for $17 \mathrm{~min}$. The temperature of the detector and injection was planned at $240^{\circ} \mathrm{C}$ and $250^{\circ} \mathrm{C}$, respectively. Identification of chromatographic peaks was carried out to the retention time of FAME standards. In the end, fatty acid compositions were shown as the percentage of total fatty acids.

\subsection{Determination of mineral and heavy metals}

The minerals and heavy metals (calcium, sodium, potassium, iron, manganese, zinc, magnesium, copper, cadmium, mercury, and lead) content of shrimp waste and carotenoproteins were determined. The nitric acid and $\mathrm{H}_{2} \mathrm{O}_{2}$ were used to digest samples. The analysis was determined by Optima 8000 ICP-OES Spectrometer (PerkinElmer, Inc., Waltham, USA).

\subsection{Statistical Analysis}

The results were analyzed using one-way analysis of variance in the completely randomized design. To compare the means Tukye' test was carried out. The analysis was accomplished by IBM SPSS Statistics 
for Windows (Version 22.0., IBM Corp. Armonk, NY., USA).

\section{Results And Discussion}

\subsection{Protein solubility of shrimp waste}

The Protein solubility of Vannami shrimp waste at different pH was determined (Fig.1). This was similar to the isoelectric $\mathrm{pH}$ of other species of shrimp. At $\mathrm{pH} 4$ to 7, the solubility of the protein was low and in the range of 1-3 and 8-10, protein had a higher solubility. At pH 6, the solubility was the lowest (1.8 $\mathrm{mg} / \mathrm{ml}$ ). This $\mathrm{pH}$ was determined 5.78 for the brown shrimp [13]. This solubility is extremely related to $\mathrm{pH}$; which at the isoelectric point, the lowest protein solubility is happening. In this point, protein has a net charge to zero, and the highest isoelectric point is at high acid or basic $\mathrm{pH}$ [22].

According to Latorres, Rios [23], The low solubility of protein is related to the firm structure of macromolecule to subunits; which bounded by multiple inter and intramolecular disulfide bonds and hydrophobic interactions. Therefore, hydrolysis of shrimp waste may increase the solubility of the protein.

\subsection{Effect of different types and levels of enzymes and hydrolysis times on the recovered carotenoprotein from shrimp waste}

The effect of different levels of enzymes (alcalase and pepsin) and times of hydrolysis incubation on the recovery of protein and carotenoid from shrimp waste has shown in Fig. 2 \& 3.

As expected, with increasing time of hydrolysis and concentration of enzymes, recovery of carotenoid and protein was increased. These recoveries significantly increased at higher units of the enzyme (3U/g). The control batch proved that enzymes in all levels had positive results on the proteolysis of shrimp waste and carotenoid extraction. Nevertheless, in protein recovery a higher level of the enzymes (>2 U/g) was more effective $(p<0.05)$; which it was previously reported by Sila, Nasri [2]. No significant differences in protein and carotenoid recoveries were considerable at levels of 3 and $4 \mathrm{U} / \mathrm{g}$ enzymes. In both enzymes, the hydrolysis of the waste was increased after $2 \mathrm{~h}$; then, a slower rate of hydrolysis was found 180 min up to $240 \mathrm{~min}$ and reached to the equilibrium phase $(\mathrm{p}>0.05)$. No significant differences in recoveries were observed after 180 min of hydrolysis. The comparison of enzymes showed that the alcalase was more effective than pepsin in the recovery of compounds from white shrimp waste $(p<0.05)$. The highest recovery of protein by $3 \mathrm{U} / \mathrm{g}$ of pepsin and alcalase was 55.85 and $50.1 \%$, respectively; which had no significant difference by 4 units of the enzymes. In the case of carotenoid recovery, the higher content was 532.14 and $531.21 \mathrm{mg} / \mathrm{g}$ for alcalase and pepsin at a concentration of $3.0 \mathrm{U} / \mathrm{g}$ of SW. Barse, Chakrabarti [24] reported that trypsin was more effective than papain and pepsin for extracting carotenoprotein from shrimp shell. Related results were also observed by Klomklao, Benjakul [25], Sila, Nasri [2] and Senphan, Benjakul [11] when different concertation and type of proteases were applied for hydrolysis of shrimp wastes to the recovery of carotenoid and protein. The enzyme levels are various in different studies related to the activities of the enzyme. The current study 3 unit of enzymes showed acceptable results of recovery. It was inconsistent with the results of pink shrimp shells hydrolysis by a 
barbell and bovine trypsin (2 unit/g shell) [2]; while 1.2 units of trypsin enhanced the carotenoprotein extraction of tiger shrimp exoskeleton [25].

\subsection{Proximate composition of shrimp waste and carotenoproteins}

The proximate compositions and chitin contents of shrimp waste were $35.71 \%$ protein, $1.75 \%$ lipid, $39.42 \%$ ash, and $22.48 \%$ (Table 1).

\section{Table 1.}

Proximate composition of the raw waste and carotenoprotein extracted with the aid of Alcalase (CPA) and Pepsin (CP-P) from shrimp (Litopenaeus vannamei) shell

\begin{tabular}{|llll|}
\hline Proximate composition & Shrimp waste & \multicolumn{2}{l|}{ Carotenoprotein } \\
\cline { 3 - 4 } & & CP-A & CP-P \\
\hline Protein (\%) & $35.71 \pm 1.43^{\mathrm{b}}$ & $75.32 \pm 1.09^{\mathrm{a}}$ & $72.11 \pm 0.42^{\mathrm{a}}$ \\
\hline Lipid (\%) & $1.75 \pm 0.25^{\mathrm{c}}$ & $20.49 \pm 0.96^{\mathrm{a}}$ & $15.72 \pm 0.44^{\mathrm{b}}$ \\
\hline Ash (\%) & $39.42 \pm 3.92^{\mathrm{a}}$ & $3.95 \pm 0.24^{\mathrm{b}}$ & $8.30 \pm 1.21^{\mathrm{b}}$ \\
\hline Chitin (\%) & $22.48 \pm 2.95^{\mathrm{a}}$ & $1.61 \pm 0.37^{\mathrm{b}}$ & $2.47 \pm 0.33^{\mathrm{b}}$ \\
\hline Carotenoids $\left(\boldsymbol{\mu g} \mathbf{g}^{-1}\right)$ & $24.06 \pm 2.05^{\mathrm{c}}$ & $530.37 \pm 6.86^{\mathrm{a}}$ & $330.00 \pm 4.07^{\mathrm{b}}$ \\
\hline Data expressed as means of three replicates \pm standard errors & \\
\hline Different letters show the significant difference between treatments $(\mathrm{P}<0.05)$. & \\
\hline
\end{tabular}

Protein in various shrimp shells has been reported about 31 to $49 \%[2,11,26]$. Due to the great protein content of the waste, this source could be used directly to the formulations for feed [26]. The max protein content in the CP-A and CP-P was 75.32 and $72.11 \%$, respectively ( $p>0.05)$; which is within the range of 71.09 to 80.05 reported by previous studies $[2,27]$. Higher protein content in carotenoproteins than the raw waste could be attributed to the removal of insoluble solid matter besides protein solubilization by enzymatic hydrolysis $[14,28]$. The carotenoid content in the SW was close to $24.06 \mathrm{\mu g} \mathrm{g}^{-1}$, which was within the range of $35.8 \mu \mathrm{g} \mathrm{g}^{-1}$ tiger a prawn ( $P$ monodon) from 23 to $331 \mu \mathrm{g} \mathrm{g}^{-1}$ in the exoskeleton reported by previous studies. It depends on species, nutritional and rearing conditions. Due to effect of proteases, the total carotenoid in CP-A $\left(530.37 \mathrm{\mu g} \mathrm{g}^{-1}\right)$ and CP-P was significantly higher than raw material; which is in agreement with the other findings [18, 25]. Sila, Nasri [2] reported $140 \mu \mathrm{g} \mathrm{g}^{-1}$ carotenoid in carotenoprotein extracted of pink shrimp waste. The extracted carotenoprotein was found to have antioxidant activity as the result of the higher content of carotenoid which is bounded to the proteins [11]. Therefore, higher content of carotenoid will cause of the antioxidant activity of the CPs. It was also observed about lipid content in CPs compared with that found in SW; which CP-A had a higher content of carotenoid and lipid in comparison of CP-P. The chitin and ash content was relatively lower in 
CP-P \& CP-A (2.47 and 1.61\%) compared with that found in SW (22.48\%); which it was inconsistent with Chakrabarti [13] also found that carotenoprotein from tropical brown shrimp shell waste extracted by trypsin had lower ash and chitin contents than shrimp waste. Our findings are in line with previous works reported by Sila, Nasri [2] and Senphan, Benjakul [11] who found high chitin at shrimp residue and the lower content in recovered CP of pink and white shrimps. It has been described that extraction by protease promotes the outgoing of protein, and lipid from shrimp residues, whiles chitin maintained in the shell $[11,25]$. According to these results, enzyme-derived CP can be used as a source of pigments, protein, and fats for human dietary supplements and salmon breeding [25].

\subsection{Color of shrimp waste and carotenoproteins}

The color parameters of SW and recovered CPs are presented in Table 2. L* value (Lightness) was found to be significantly higher in the SW; which was significantly lower in CP-A and CP-P. SW had significantly lower $a^{*}$ and $b *$ values $(p<0.05)$.

\section{Table 2.}

Color indexes of the raw waste and carotenoprotein extracted with the aid of Alcalase (CP-A) and Pepsin (CP-P) from shrimp (Litopenaeus vannamei) shell

\begin{tabular}{|llll|} 
& Shrimp waste & \multicolumn{2}{l|}{ Carotenoprotein } \\
\cline { 3 - 4 } & & CP-A & CP-P \\
\hline$L^{*}$ & $70.40 \pm 1.05^{\mathrm{a}}$ & $36.1 \pm 0.00^{\mathrm{b}}$ & $41.60 \pm 0.00^{\mathrm{b}}$ \\
\hline $\mathbf{a}^{*}$ & $9.06 \pm 2.05^{\mathrm{b}}$ & $38.60 \pm 0.80^{\mathrm{a}}$ & $32.05 \pm 0.75^{\mathrm{a}}$ \\
\hline $\boldsymbol{b}^{*}$ & $16.10 \pm 2.05^{\mathrm{c}}$ & $42.90 \pm 0.75^{\mathrm{c}}$ & $40.25 \pm 0.50^{\mathrm{c}}$ \\
\hline Data expressed as means of three replicates \pm standard errors & \\
\hline
\end{tabular}

The recovered CP-A and CP-P samples were orange-red in color and CP-A showed higher redness of $38.60\left(a^{\star}\right)$ and yellowness of $42.90\left(b^{\star}\right)$. Higher values of $a^{\star}$ and $b^{\star}$ was related to the extracted astaxanthin along with protein. These results agreed with that reported by Senphan, Benjakul [11] and Sila, Sayari [27] in a studies on obtained carotenoproteins by proteases; which reported lower lightness and higher $a^{*}$ and $b^{*}$ in CPs than shrimp waste. Crustacean color depends on the astaxanthin content that causes a range of color from green, yellow, blue to brown. The deposited astaxanthin is responsibility of the color and hue saturation of crustacean [29]; which could be used as a coloring agent in feed or maybe food.

\subsection{Amino acid composition}


The essential and non- essential of amino acids were found at Pacific white shrimp waste (Table 3).

The shrimp waste has a significant content of the essential amino acids such as phenylalanine, lysine, valine and leucine (155.34, 73.04, 59.00 and $58.05 \mathrm{mg} / \mathrm{g}$ sample, respectively). The non-essential amino acids such as glutamic acid, arginine, aspartic acid, and glycine also have been identified in amino acid profiles of shrimp waste $(109.35,82.05,73.04$, and $62.07 \mathrm{mg} / \mathrm{g}$ sample, respectively). Carotenoproteins extracted from shrimp shells had higher total non-essential amino acid $(660.06 \& 606.23 \mathrm{mg} / \mathrm{g})$ level than shrimp waste $(529.67 \mathrm{mg} / \mathrm{g})$. The CPs was a significant source of the non-essential amino acids such as arginine (101.05 \& $93.20 \mathrm{mg} / \mathrm{g}$ sample, respectively); which was higher in alcalase treated waste. 


\section{Table 3.}

Amino acid composition of the raw waste and carotenoprotein extracted with the aid of Alcalase (CP-A) and Pepsin (CP-P) from shrimp (Litopenaeus vannamei) shell

\begin{tabular}{|c|c|c|c|}
\hline Amino acid & Raw waste & CP-A & CP-P \\
\hline Histidine & $38.00 \pm 0.09^{a}$ & $29.05 \pm 0.05^{c}$ & $33.00 \pm 0.09^{b}$ \\
\hline Leucine & $58.05 \pm 0.05^{a}$ & $57.16 \pm 0.05^{b}$ & $32.00 \pm 2.29^{a}$ \\
\hline Isoleucine & $32.05 \pm 0.05^{\mathrm{a}}$ & $22.15 \pm 0.25^{b}$ & $11.01 \pm 0.01^{c}$ \\
\hline Lysine & $73.00 \pm 0.20^{\mathrm{a}}$ & $74.01 \pm 0.09^{a}$ & $54.24 \pm 0.33^{b}$ \\
\hline Methionine & $18.00 \pm 0.10^{b}$ & $14.99 \pm 0.02^{c}$ & $24.70 \pm 0.10^{a}$ \\
\hline phenylalanine & $155.34 \pm 1.35^{\mathrm{a}}$ & $75.04 \pm 0.06^{c}$ & $124.74 \pm 4.75^{a}$ \\
\hline Threonine & $35.01 \pm 0.01^{c}$ & $55.20 \pm 0.10^{a}$ & $44.25 \pm 0.45^{b}$ \\
\hline Valine & $59.00 \pm 0.09^{b}$ & $61.01 \pm 0.00^{a}$ & $42.05 \pm 0.25^{c}$ \\
\hline Cystein & $37.05 \pm 0.05^{a}$ & $31.00 \pm 1.00^{\mathrm{b}}$ & $31.06 \pm 0.04^{b}$ \\
\hline Aspartic acid & $73.04 \pm 0.05^{c}$ & $111.01 \pm 1.01^{\mathrm{a}}$ & $107.13 \pm 3.02^{b}$ \\
\hline Glutamic acid & $109.35 \pm 0.36^{c}$ & $142.89 \pm 0.08^{a}$ & $131.01 \pm 0.11^{\mathrm{b}}$ \\
\hline Serine & $46.05 \pm 0.05^{a}$ & $38.05 \pm 0.05^{c}$ & $41.10 \pm 0.10^{b}$ \\
\hline Glycine & $62.07 \pm 2.18^{c}$ & $90.89 \pm 0.09^{a}$ & $72.05 \pm 0.05^{b}$ \\
\hline Arginine & $82.05 \pm 0.05^{c}$ & $101.05 \pm 0.05^{a}$ & $93.20 \pm 0.20^{b}$ \\
\hline Alanine & $48.05 \pm 0.05^{c}$ & $83.04 \pm 0.05^{a}$ & $72.50 \pm 0.19^{b}$ \\
\hline Proline & $38.95 \pm 0.04^{c}$ & $42.05 \pm 0.05^{\mathrm{a}}$ & $40.06 \pm 0.02^{b}$ \\
\hline Tyrosin & $33.05 \pm 0.05^{\mathrm{a}}$ & $20.05 \pm 0.05^{b}$ & $18.11 \pm 0.01^{\mathrm{c}}$ \\
\hline Essential amino acids & $468.46 \pm 1.73^{a}$ & $388.62 \pm 0.41^{b}$ & $366.00 \pm 7.57^{c}$ \\
\hline Non-essential amino acids & $529.67 \pm 2.39^{c}$ & $660.06 \pm 0.13^{a}$ & $606.23 \pm 2.97^{b}$ \\
\hline Total Amino acids & $998.14 \pm 4.13^{b}$ & $1048.68 \pm 0.28^{a}$ & $972.24 \pm 10.54^{\mathrm{c}}$ \\
\hline
\end{tabular}


Due to degradation during hydrolysis, tryptophan was not in any sample. Carotenporoteins recovered by alcalase and pepsin were a significant source of the non-essential amino acids glutamic acid, aspartic acid, glycine, alanine $(p<0.05)$. The phenylalanine, lysine and valine as essential amino acids were high at alcalase treated waste; while phenylalanine and lysine were at a higher concentration (124.74 \& 54.24 $\mathrm{mg} / \mathrm{g}$ ) in CP-P. The non-essential amino acids aspartic acid, glutamic acid, glycine and alanine were found in higher concentrations in both carotenoproteins; which alcalase treated waste displayed higher content amino acids. It was inconsistent by Pattanaik, Sawant [12] reporting between all amino acids, glutamic acid was in the main and high amount in all the CPs extracted from different shrimp species. It was also in agreement with the findings of Senphan, Benjakul [11], Klomklao, Benjakul [25] who reported that the CPs was abundant in these amino acids.

In similar study, the essential amino acids in carotenoprotein of L. vannami shrimp waste reported higher than the current study [11]. Armenta and Guerrero-Legarreta (2009) showed that carotenoprotein extracted from fermented vannami shrimp waste was rich in aspartic acid and glutamic acids. Cremades, Parrado [30] , expressed that carotenoproteins could develop diets for patients who are suffering from specific diseases such as cancer-anorexia-cachexia syndrome and renal damage.

\subsection{Fatty acid composition}

Fatty acid compositions of shrimp waste and extracted carotenoprotein by different enzymes are presented in Table 4 . The fatty acid profile of shrimp shell could be related to species differences and also farming and/or feeding conditions. 


\section{Table 4}

Fatty acid profile (\% of total fatty acids) of the raw waste and carotenoprotein extracted with the aid of Alcalase (CP-A) and Pepsin (CP-P) from shrimp (Litopenaeus vannamei) shell

\section{Fatty acids \\ WS Carotenoprotein}

CP-A CP-P

$\begin{array}{llll}\text { C12:0 } & 1.70 \pm 0.01 & 1.10 \pm 0.00 & 0.81 \pm 0.00 \\ \text { C14:0 } & 3.09 \pm 0.00 & 1.11 \pm 0.00 & 2.39 \pm 0.05 \\ \text { C15:0 } & 1.70 \pm 0.00 & 0.50 \pm 0.01 & 1.30 \pm 0.01 \\ \text { C16:0 } & 15.29 \pm 0.00 & 6.41 \pm 0.01 & 8.60 \pm 0.02 \\ \text { C18:0 } & 6.20 \pm 0.00 & 2.25 \pm 0.16 & 4.20 \pm 0.00 \\ \text { C20:0 } & 0.39 \pm 0.01 & 0.94 \pm 0.04 & 0.51 \pm 0.00\end{array}$

unknown

$1.45 \pm 0.04$

$0.50 \pm 0.00$

$0.79 \pm 0.01$

SFA

$29.85 \pm 0.01^{\mathrm{a}}$

$12.82 \pm 0.11^{\mathrm{C}}$

$18.63 \pm 0.04^{b}$

C16:1n-7

$4.81 \pm 0.00$

$5.86 \pm 0.08$

$5.79 \pm 0.03$

C16:1n-5

$1.38 \pm 0.01$

$2.50 \pm 0.00$

2. $21 \pm 0.01$

C18:1n-9

$10.31 \pm 0.08$

$8.29 \pm 0.02$

$7.50 \pm 0.00$

C18:1n-7

$5.08 \pm 0.02$

$7.20 \pm 0.00$

$6.58 \pm 0.06$

C20:1n-9

$2.15 \pm 0.05$

$4.20 \pm 0.00$

$3.30 \pm 0.00$

C20:1n-7

$1.51 \pm 0.00$

$1.80 \pm 0.00$

$2.10 \pm 0.09$

C22:1n-9

$1.09 \pm 0.00$

$2.43 \pm 0.03$

$1.93 \pm 0.03$

C22:1n-7

$0.20 \pm 0.00$

$0.52 \pm 0.02$

$0.81 \pm 0.01$

unknown

$0.80 \pm 0.00$

$0.49 \pm 0.00$

$0.51 \pm 0.02$

MUFA

$27.37 \pm 0.17^{\mathrm{C}}$

$33.31 \pm 0.04^{\mathrm{a}}$

$30.76 \pm 0.18^{b}$

C16:2n-9

$1.80 \pm 0.00$

$2.20 \pm 0.00$

$1.59 \pm 0.04$

C16:2n-4

$2.09 \pm 0.02$

$3.23 \pm 0.03$

$2.80 \pm 0.00$

C16:3n-4

$1.22 \pm 0.02$

$1.70 \pm 0.01$

$0.89 \pm 0.02$

C16:4n-3

$1.59 \pm 0.00$

$0.28 \pm 0.01$

$0.83 \pm 0.03$

C18:2n-6

$1.76 \pm 0.08$

$1.51 \pm 0.01$

$0.68 \pm 0.01$

C18:2n-4

$0.60 \pm 0.01$

$0.26 \pm 0.04$

$0.50 \pm 0.00$ 


\begin{tabular}{|llll|}
\hline C18:3n-4 & $0.50 \pm 0.08$ & $0.41 \pm 0.01$ & $0.80 \pm 0.00$ \\
\hline C18:3n-3 & $0.79 \pm 0.06$ & $1.80 \pm 0.00$ & $1.41 \pm 0.05$ \\
\hline C20:2n-9 & $3.10 \pm 0.00$ & $3.60 \pm 0.00$ & $3.11 \pm 0.01$ \\
\hline C20:2n-6 & $2.00 \pm 0.00$ & $2.50 \pm 0.00$ & $2.14 \pm 0.04$ \\
\hline C20:4n-6 & $4.19 \pm 0.00$ & $5.21 \pm 0.01$ & $4.51 \pm 0.01$ \\
\hline C20:5n-3 & $4.79 \pm 0.00^{\mathrm{C}}$ & $6.49 \pm 0.00^{\mathrm{a}}$ & $5.49 \pm 0.00^{\mathrm{b}}$ \\
\hline C22:4n-6 & $0.88 \pm 0.01$ & $1.52 \pm 0.00$ & $1.39 \pm 0.02$ \\
\hline C22:5n-6 & $1.10 \pm 0.00$ & $2.20 \pm 0.00$ & $2.82 \pm 0.02$ \\
\hline C22:5n-3 & $1.69 \pm 0.00$ & $2.70 \pm 0.00$ & $2.10 \pm 0.09$ \\
\hline C22:6n-3 & $5.50 \pm 0.00^{\mathrm{b}}$ & $8.52 \pm 0.02^{\mathrm{a}}$ & $5.55 \pm 0.15^{\mathrm{b}}$ \\
\hline unknown & $0.19 \pm 0.03$ & $0.85 \pm 0.05$ & $1.80 \pm 0.02$ \\
\hline PUFA & $33.85 \pm 0.22^{\mathrm{C}}$ & $45.06 \pm 0.04^{\mathrm{a}}$ & $38.58 \pm 0.03^{\mathrm{b}}$ \\
\hline Data expressed as means of two replicates \pm standard errors & \\
\hline Different letters show the significant difference between treatments $(\mathrm{P}<0.05)$. \\
\hline
\end{tabular}

Shrimp waste exhibited a desirable content of PUFAs (33.85\%); which were found to be more abundant than MUFAs and SFAs (27.37 and 29.85, respectively). The most abundant SFAs in SW were Palmitic (C16:0) (15.29\%) and Stearic acids (C18:0) (6.20\%) and the main MUFA was oleic acid (C18:1 n-9); among the PUFAs, DHA (C22:6n-3) and EPA (C20:5n-3) were the main PUFAs (5.50 and $4.79 \%$, respectively) in shrimp waste. It was inconsistent of similar studies on pink shrimp shell fatty acids; which palmitic, stearic and oleic acid was prevail in the shells. Total PUFA in this study was more than the reported of pink shrimp shells (22.48\%) [2]. The SFAs were reduced after enzymatic hydrolysis and MUFA and PUFA contents were higher in carotenoproteins $(p<0.05)$. The high content of PUFA and the ratio of PUFA/SFA descending orders were: $C P-A>C P-P>W S$. The lowest ratio of total $\omega 6$ to $\omega 3$ was in CP-A samples. Palmitic acid, oleic acid, DHA and EPA were found to be higher than other fatty acids of CP-A and CP-P; which CP-A showed higher DHA and EPA (8.52 and 6.49\%) than CP-P (5.55 and 5.49\%). According to , Cremades, Parrado [30] recovered CP from crayfish contained significant content of $\omega 3$ and $\omega 6$ fatty acids which bound to protein and make this compound as a nutraceutical product.

\subsection{Mineral and Heavy metal composition}

Table 5 shows the mineral and heavy metal compositions of the shrimp waste and recovered carotenoproteins. Minerals are essential to several important biochemical and physiological functions in 
the body [31]. In the present study, SW contained substantial amounts of calcium, phosphorus, and sodium.

\section{Table5.}

Mineral and heavy metals $(\mathrm{mg} / 100 \mathrm{~g})$ content of the raw waste and carotenoprotein extracted with the aid of Alcalase (CP-A) and Pepsin (CP-P) from Pacific white shrimp (Litopenaeus vannamei) shell

\begin{tabular}{|c|c|c|c|}
\hline & \multirow[t]{2}{*}{ Shrimp waste } & \multicolumn{2}{|l|}{ Carotenoprotein } \\
\hline & & CP-A & CP-P \\
\hline $\mathrm{Ca}$ (calcium) & $2547.50 \pm 27.50$ & Trace & Trace \\
\hline Ph (phosphorus) & $313.00 \pm 12.00^{a}$ & $101.0 \pm 1.00^{\mathrm{b}}$ & $101.00 \pm 1.00^{\mathrm{b}}$ \\
\hline Mg (Magnesium) & $120.50 \pm 3.49^{a}$ & $47.5 \pm 0.50^{b}$ & $47.5 \pm 0.50^{b}$ \\
\hline $\mathrm{Na}$ (Sodium) & $278.50 \pm 6.50^{a}$ & $100.50 \pm 10.50^{b}$ & $315.50 \pm 15.25^{a}$ \\
\hline K (potassium) & $53.00 \pm 5.00^{a}$ & $39.50 \pm 0.50^{b}$ & $39.51 \pm 0.50^{b}$ \\
\hline Mn (Manganese) & $4.95 \pm 0.15^{\mathrm{a}}$ & $1.60 \pm 0.50^{\mathrm{b}}$ & $1.20 \pm 0.50^{b}$ \\
\hline Fe (Iron) & $4.65 \pm 0.55^{a}$ & $3.95 \pm 0.15^{b}$ & $2.87 \pm 0.27^{c}$ \\
\hline $\mathrm{Hg}$ (Mercury) & Trace & Trace & Trace \\
\hline $\mathrm{Pb}$ (Lead) & $0.15 \pm 0.05$ & Trace & Trace \\
\hline Zn (Zinc) & $4.95 \pm 0.25^{\mathrm{a}}$ & $2.40 \pm 0.30^{b}$ & $2.26 \pm 0.50^{b}$ \\
\hline Cd (Cadmium) & Trace & Trace & Trace \\
\hline Cu (Copper) & $10.00 \pm 0.20^{\mathrm{a}}$ & $4.75 \pm 0.45^{b}$ & $4.32 \pm 0.13^{b}$ \\
\hline \multicolumn{4}{|c|}{ Values are mean $\pm S D(n=3)$} \\
\hline \multicolumn{4}{|c|}{ Different letters in each row denote significant difference $(P<0.05)$. } \\
\hline
\end{tabular}

It was likely due to the existence of wide concentrations of the minerals in the raw material. Sodium, phosphorus, magnesium and potassium contents were found to be higher in CPs. The mineral content in CPs was affected by substrate and enzyme. Chalamaiah, Hemalatha [31] also considered the effect of enzyme and substrate type on the mineral type and content in hydrolyzed roe samples. The minerals in the SW were higher than CPs; which calcium mainly found in higher quantity in waste. Furthermore, except of sodium, the mineral contents no significant difference observed among CP-P and CP-A. Due to the neutralization of acidic $\mathrm{pH}$ by addition $\mathrm{NaOH}$; sodium was mainly in higher quantity in $\mathrm{CP}-\mathrm{P}$ [32]. In $\mathrm{CP}-\mathrm{A}$ and $\mathrm{CP}-\mathrm{P}$, phosphorus and magnesium contents were significantly reduced than raw material. 
Regarding the heavy metals, the lead was in SW; which it was eliminated in the CPs (Table 3). The elements decreased significantly after enzymatic hydrolysis. The presence of heavy metals in shrimp waste depends on the content of metals in the water and the breeding area. Copper, zinc and iron are among essential heavy metals. According to Wu and Yang [33], the amount of $\mathrm{Zn}$ and Fe elements are a reflect of aquatic environments. These essential heavy metals decreased in $\mathrm{CPs}$; which were higher in $\mathrm{CP}$ A samples.

\section{Conclusion}

Results of the present study showed the characteristics of the extracted carotenporoteins from shrimp processing residues. The optimum conditions for the higher extracted content of carotenoid and protein by alcalase and pepsin were found. The maximum yield was found by the alcalase at $3 \mathrm{U} / \mathrm{g}$ during 180 min of incubation time $(\mathrm{pH}=8)$. The study showed the potential of the raw shell of Litopenaeus vannami can be a source of protein and mineral contents. The carotenoproteins had a higher content of fatty acids and essential and non-essential amino acids. This bio-macromolecule contained an acceptable level of mineral contents. The co-extraction of protein and carotenoid as a bioactive and antioxidant powder could be used as an additive to enrich some daily foods. Further, researches are required to assess in this area.

\section{Abbreviations}

CPs, carotenoproteins; CP-A, Carotenoprotein recovered by Alcalase; CP-P, Carotenoprotein recovered by Pepsin; SW, shrimp waste; SFA, Saturated Fatty Acids; MUFA, Mono Unsaturated Fatty Acids; PUFA, Poly Unsaturated Fatty Acids; BSA, Bovine Serum Albumin; BF3, Boron triFluoride; FAMEs, fatty acid methyl esters;

\section{Declarations}

\section{Authorship principles}

Parastoo Pourashouri: Supervision, Conceptualization, Formal analysis, Writing- Reviewing and Editing; Hojat Mirsadeghi: Methodology, Data Curation, Resources; Aynaz khodanazary: Visualization, Investigation

\section{Conflicts of Interest}

The authors declare that they have no known competing financial interests or personal relationships that could have appeared to influence the work reported in this paper.

\section{References}


1. Morales-Medina, R., et al., Functional and antioxidant properties of hydrolysates of sardine ( $S$. pilchardus) and horse mackerel (T. mediterraneus) for the microencapsulation of fish oil by spraydrying. Food Chemistry, 2016. 194: p. 1208-1216.

2. Sila, A., M. Nasri, and A. Bougatef, Isolation and characterisation of carotenoproteins from deepwater pink shrimp processing waste. International Journal of Biological Macromolecules, 2012. 51(5): p. 953-959.

3. Sila, A., et al., Ability of natural astaxanthin from shrimp by-products to attenuate liver oxidative stress in diabetic rats. Pharmacological Reports, 2015. 67(2): p. 310-316.

4. Gómez-Estaca, J., et al., Characterization and storage stability of astaxanthin esters, fatty acid profile and a-tocopherol of lipid extract from shrimp (L. vannamei) waste with potential applications as food ingredient. Food Chemistry, 2017. 216: p. 37-44.

5. Sowmya, R., K. Rathinaraj, and N.M. Sachindra, An Autolytic Process for Recovery of Antioxidant Activity Rich Carotenoprotein from Shrimp Heads. Marine Biotechnology, 2011. 13(5): p. 918-927.

6. Sachindra, N.M., N. Bhaskar, and N.S. Mahendrakar, Recovery of carotenoids from shrimp waste in organic solvents. Waste Management, 2006. 26(10): p. 1092-1098.

7. Takeungwongtrakul, S. and S. Benjakul, Oxidative stability of lipids from hepatopancreas of Pacific white shrimp (Litopenaeus vannamei) as affected by essential oils incorporation. European Journal of Lipid Science and Technology, 2014. 116(8): p. 987-995.

8. Nasri, R., et al., Digestive alkaline proteinases from Serranus scriba viscera: Characteristics, application in the extraction of carotenoproteins from shrimp waste, and evaluation in laundry commercial detergents. Biocatalysis and Agricultural Biotechnology, 2015. 4(3): p. 355-361.

9. Mechri, S., et al., A biological clean processing approach for the valorization of speckled shrimp Metapenaeus monoceros by-product as a source of bioactive compounds. Environmental Science and Pollution Research, 2020. 27(13): p. 15842-15855.

10. Sowmya, R. and N.M. Sachindra, Evaluation of antioxidant activity of carotenoid extract from shrimp processing byproducts by in vitro assays and in membrane model system. Food Chemistry, 2012. 134(1): p. 308-314.

11. Senphan, T., S. Benjakul, and H. Kishimura, Characteristics and antioxidative activity of carotenoprotein from shells of Pacific white shrimp extracted using hepatopancreas proteases. Food Bioscience, 2014. 5: p. 54-63.

12. Pattanaik, S.S., et al., Characterization of carotenoprotein from different shrimp shell waste for possible use as supplementary nutritive feed ingredient in animal diets. Aquaculture, 2020. 515: p. 734594.

13. Chakrabarti, R., CAROTENOPROTEIN FROM TROPICAL BROWN SHRIMP SHELL WASTE BY ENZYMATIC PROCESS. Food Biotechnology, 2002. 16(1): p. 81-90.

14. Armenta, R.E. and I. Guerrero-Legarreta, Amino acid profile and enhancement of the enzymatic hydrolysis of fermented shrimp carotenoproteins. Food Chemistry, 2009. 112(2): p. 310-315. 
15. Kannan, A., et al., Shrimp shell peptide hydrolysates inhibit human cancer cell proliferation. Journal of the Science of Food and Agriculture, 2011. 91(10): p. 1920-1924.

16. Gildberg, A. and E. Stenberg, A new process for advanced utilisation of shrimp waste. Process Biochemistry, 2001. 36(8): p. 809-812.

17. Poonsin, T., et al., Albacore tuna spleen trypsin: Potential application as laundry detergent additive and in carotenoprotein extraction from Pacific white shrimp shells. Biocatalysis and Agricultural Biotechnology, 2019. 17: p. 638-646.

18. Poonsin, T., et al., Carotenoprotein from Pacific white shrimp (Litopenaeus vannamei) shells extracted using trypsin from albacore tuna (Thunnus alalunga) spleen: Antioxidant activity and its potential in model systems. Journal of Food Biochemistry, 2018. 42(2): p. e12462.

19. Gornall, A.G., C.J. Bardawill, and M.M. David, Determination of serum proteins by means of the biuret reaction. J Biol Chem, 1949. 177(2): p. 751-66.

20. AOAC, Official Methods of Analysis. 2002: Gaithersburg, MD.

21. Metcalfe, L.D. and A.A. Schmitz, The Rapid Preparation of Fatty Acid Esters for Gas Chromatographic Analysis. Analytical Chemistry, 1961. 33(3): p. 363-364.

22. Gómez-Estaca, J., P. Montero, and M.C. Gómez-Guillén, Chemical characterization of wash water biomass from shrimp surimi processing and its application to develop functional edible films. Journal of Food Science and Technology, 2018. 55(10): p. 3881-3891.

23. Latorres, J.M., et al., Functional and antioxidant properties of protein hydrolysates obtained from white shrimp (Litopenaeus vannamei). Journal of Food Science and Technology, 2018. 55(2): p. 721 729.

24. Barse, A.V., et al., Endocrine disruption and metabolic changes following exposure of Cyprinus carpio to diethyl phthalate. Pesticide Biochemistry and Physiology, 2007. 88(1): p. 36-42.

25. Klomklao, S., et al., EXTRACTION OF CAROTENOPROTEIN FROM BLACK TIGER SHRIMP SHELLS WITH THE AID OF BLUEFISH TRYPSIN. Journal of Food Biochemistry, 2009. 33(2): p. 201-217.

26. Sánchez-Camargo, A.P., et al., Proximate composition and extraction of carotenoids and lipids from Brazilian redspotted shrimp waste (Farfantepenaeus paulensis). Journal of Food Engineering, 2011. 102(1): p. 87-93.

27. Sila, A., et al., Biochemical and antioxidant properties of peptidic fraction of carotenoproteins generated from shrimp by-products by enzymatic hydrolysis. Food Chemistry, 2014. 148: p. 445-452.

28. Ghelichi, S., B. Shabanpour, and P. Pourashouri, Properties of Fish Sausages Containing Common Carp (Cyprinus carpio) Roe Oil and Defatted Roe Protein Hydrolysate during Refrigerated Storage. Journal of Aquatic Food Product Technology, 2018. 27(2): p. 185-199.

29. Wade, N.M., J. Gabaudan, and B.D. Glencross, A review of carotenoid utilisation and function in crustacean aquaculture. Reviews in Aquaculture, 2017. 9(2): p. 141-156.

30. Cremades, O., et al., Isolation and characterization of carotenoproteins from crayfish (Procambarus clarkii). Food Chemistry, 2003. 82(4): p. 559-566. 
31. Chalamaiah, M., et al., Chemical composition and immunomodulatory effects of enzymatic protein hydrolysates from common carp (Cyprinus carpio) egg. Nutrition, 2015. 31(2): p. 388-398.

32. Chalamaiah, M., et al., Chemical composition, molecular mass distribution and antioxidant capacity of rohu (Labeo rohita) roe (egg) protein hydrolysates prepared by gastrointestinal proteases. Food Research International, 2013. 52(1): p. 221-229.

33. Wu, X.-Y. and Y.-F. Yang, Heavy metal ( $\mathrm{Pb}, \mathrm{Co}, \mathrm{Cd}, \mathrm{Cr}, \mathrm{Cu}, \mathrm{Fe}, \mathrm{Mn}$ and $\mathrm{Zn}$ ) concentrations in harvestsize white shrimp Litopenaeus vannamei tissues from aquaculture and wild source. Journal of Food Composition and Analysis, 2011. 24(1): p. 62-65.

\section{Figures}

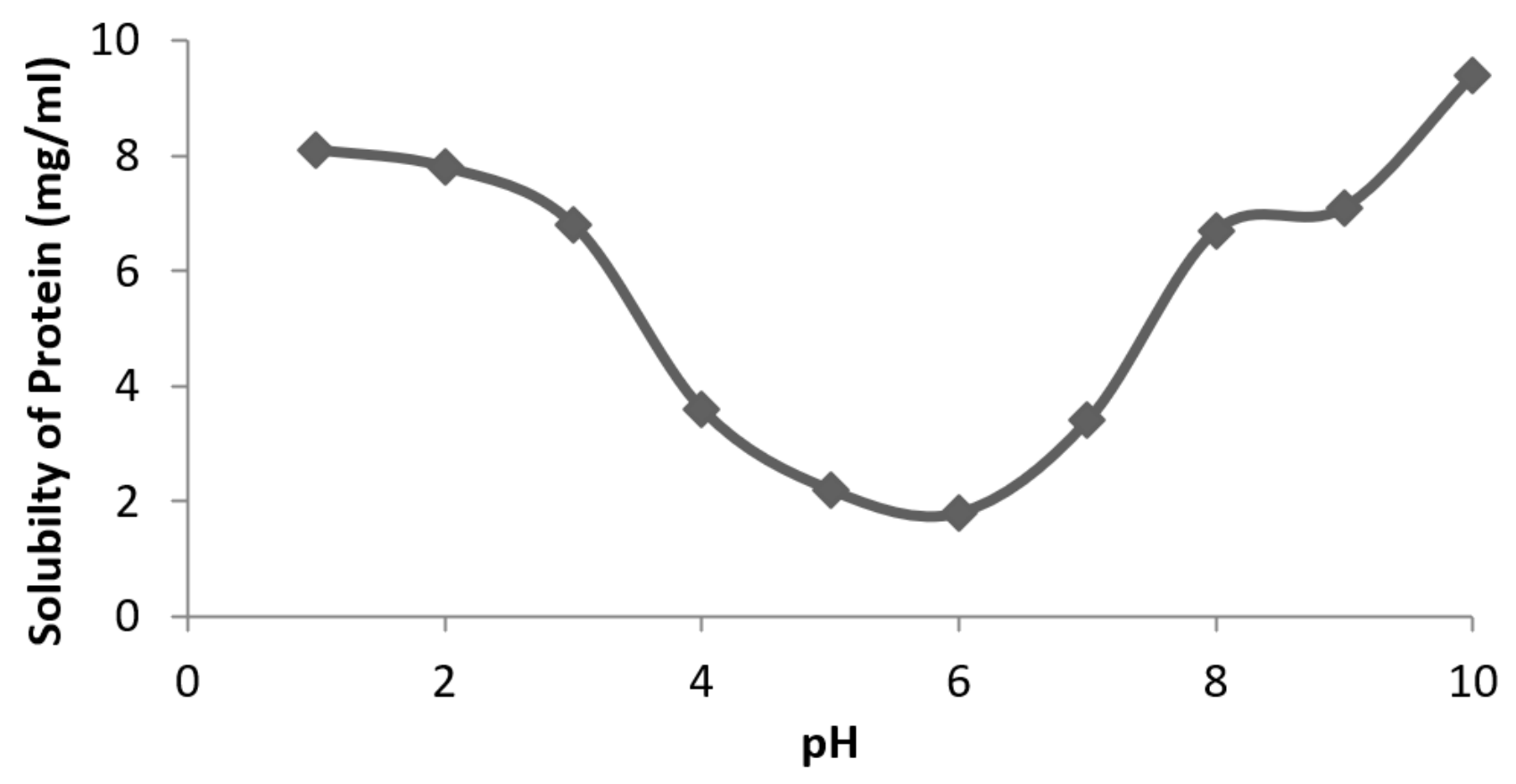

Figure 1

Solubility of protein of Pacific white shrimp (Litopenaeus vannamei) at different $\mathrm{pH}$ 

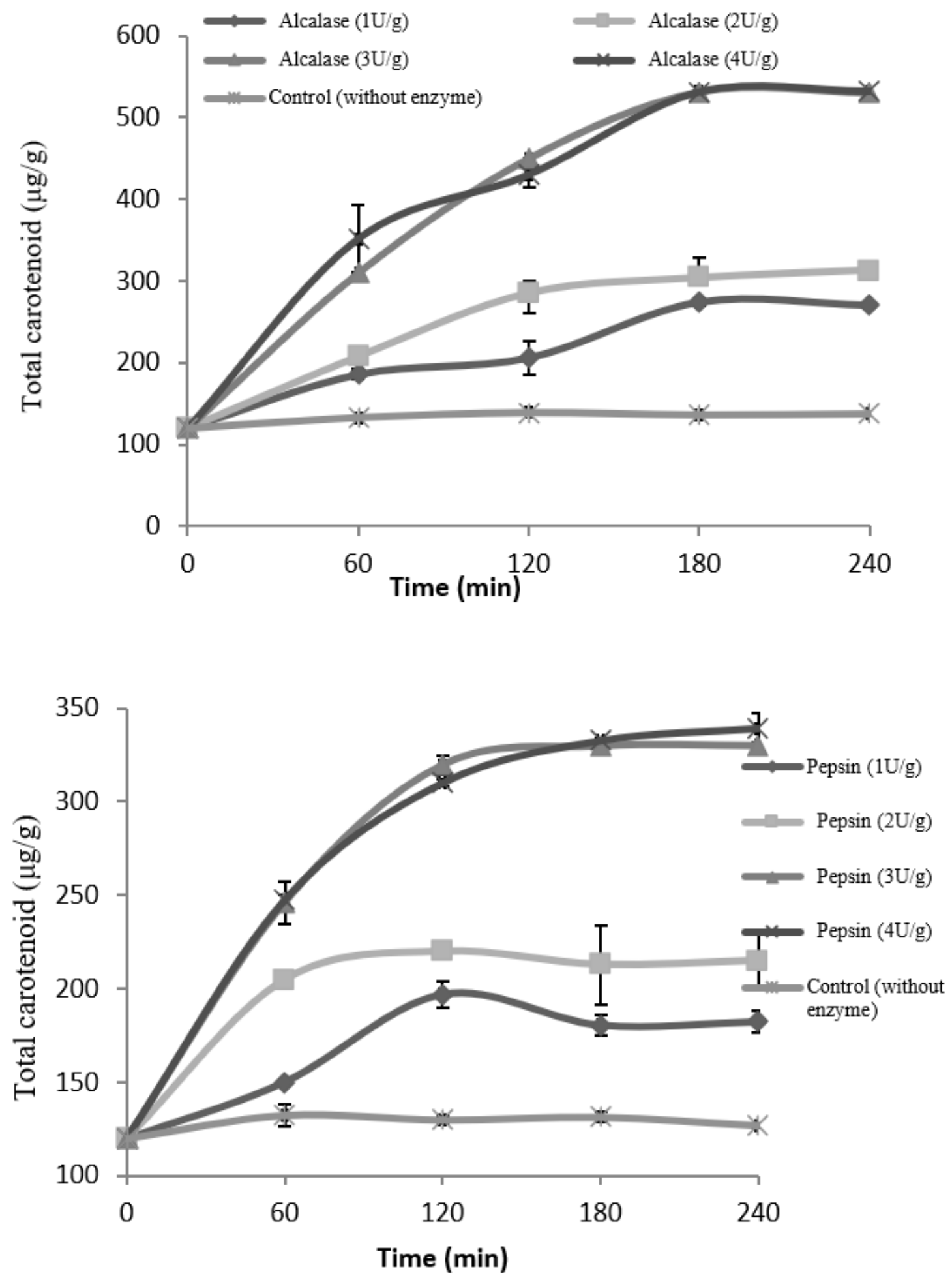

Figure 2

Total carotenoid contents of pacific white shrimp (Litopenaeus vannamei) shell with different levels of alcalase and pepsin 

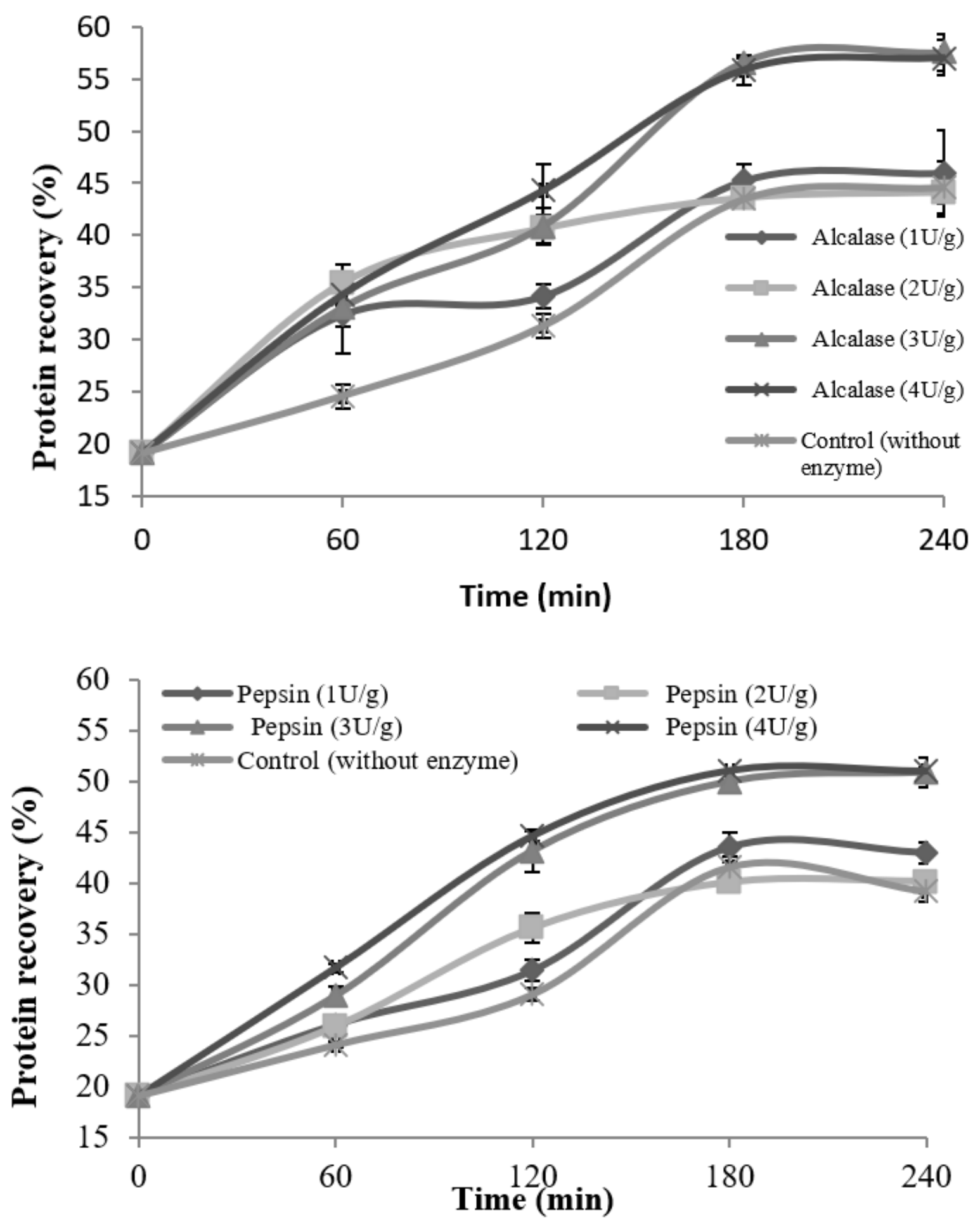

Figure 3

Protein content of pacific white shrimp (Litopenaeus vannamei) shell with different levels of alcalase and pepsin 
This is a list of supplementary files associated with this preprint. Click to download.

- GraphicalAbstract.png 